\title{
Female Education in Senior High Schools in Gomoa West District of the Central Region of Ghana: the Perspective of the Female Students
}

\author{
Linus Mwinkaar*1, Martin Ako ${ }^{2}$ \\ ${ }^{1}$ Department of Educational Studies, McCoy College of Education, Nadowli, Ghana \\ ${ }^{2}$ Department of Basic Education, Christ Apostolic University College, Kumasi, Ghana \\ E-mail: linusmwinkaar91@gmail.com
}

\begin{abstract}
The study purposed to examine female education and affirmative action in Senior High Schools in Gomoa West District of the Central region, Ghana. Three research questions were formulated to guide the study. The study used descriptive survey. The target population of the study was the Female students of the three Senior High Schools in Gomoa West District. The simple random sampling was used to get 200 respondents. The study used questionnaires for data collection and the data were analyzed using SPSS. The findings from the study showed that factors such as cultural practices and entrenched beliefs, poverty, low level of education of parents, unconducive school environment, early marriages, teacher absenteeism, parental negative attitude towards education, inadequate parental attention to girl's education, affected female education in Gomoa West district negatively. Also, measures such as provision of basic educational materials, educational training to girls, basic needs to girls, training of teachers to become Teacher Mentors to mentor girls in schools, involvement of more girls in school activities and sensitizing community against early child marriages were put in place to promote female education. Female students are satisfied with measures put in place by stakeholders in the district to promote female education. They also believed that measures and educational policies put in place to promote female education in the district are effective and impactful. Female students are also involved in school leadership and they fully participate in school activities. The researcher recommends stakeholders to continue to do more in providing girls in Senior High Schools with basic bursary items to enable them enroll in school, stay in and complete school successfully.
\end{abstract}

Keywords: female education, female students, Senior High School, affirmative action

\section{Introduction}

Education is the foundation for all types of developments in the world. It has been established that countries with an advanced educational system are the ones that are developed and making progress in the world. In any society, education has become the vital process through which it develops and it is considered as one of the main pillars of a society ${ }^{[5]}$. Education is not a charity rather a fundamental human right for all people irrespective of their sex, race, economic status and it is the key to sustainable development, peace and stability among countries ${ }^{[9]}$. In any society, the provision of education is fundamental and basic for human resource development. Education represents a major form of human resource development. Human resource development which constitutes an underlying basis upon material development is determined by the availability and quality of education. It is an important cornerstone for the nation's fast socio-economic development.

Educating females yields far-reaching benefits for girls and women themselves, their families and the societies in which they live ${ }^{[11]}$. The benefits of investing in human capital are especially pertinent for women in developing countries where gender equity in education is often lagging behind. Without educating women, national endeavours can be less effective and the efforts of women weaker ${ }^{[9]}$.

The significant contribution of female education is expressed in terms of economic, cultural and political aspect of a country. An educated female is likely to become a more competent and knowledgeable mother, a more productive and better paid worker, an informed citizen, a self-confident individual and a skilled decision maker ${ }^{[15]}$.

The social benefits of women's schooling are significant, especially in developing countries ${ }^{[9,17]}$. For example, a year of schooling for girls reduces infant mortality by 5 to 10 percent ${ }^{[17]}$. Children of mothers with five years of primary

Copyright (C2020 Linus Mwinkaar, et al.

DOI: https://doi.org/10.37256/ser.112020157.39-47

This is an open-access article distributed under a CC BY license

(Creative Commons Attribution 4.0 International License)

https://creativecommons.org/licenses/by/4.0/ 
education are 40 percent more likely to live beyond age five ${ }^{[15]}$. When the proportion of women with secondary schooling doubles, the fertility rate is reduced from 5.3 to 3.9 children per woman ${ }^{[11]}$.

There is a direct relationship between female education and poverty reduction. Educated women tend to have smaller family sizes and reduced fertility which has great potential benefits for their future generation. For instance, UNDP's statistics have indicated that the high fertility rate in Tanzania and Ghana in the early 70s (1970-75) dropped drastically from 6.8 births per woman to 5.1 and 6.9 to 4.1 respectively between 2000 and 2005 due to continued and sustained efforts in ensuring the participation of girls in education in the two countries ${ }^{[13]}$.

Girl child education benefits the girls, their families, their countries, and society in general ${ }^{[13]}$. Girls who go through the educational system are able to experience a sense of agency and empowerment. Additionally, there are concrete benefits to be gained from educating girls. The United Nations has asserted that education is especially significant for girls and women because it is an entry point to other opportunities, also because the educational achievements of women can have ripple effects within the family and across generations ${ }^{[13]}$.

However, in many developing countries, many girls receive little or no formal education and this is occurring although educating girls is vital for a variety of reasons. Girls from poor families cannot afford the expenditures of the books, uniforms and transportation to school ${ }^{[5]}$. Underprivileged and poor families are also more likely to confine their girls at home to look after younger siblings or to engage in family enterprises. If these poor families have to make decisions in order to educate son or a daughter, they select their sons because of poor financial status. Consequently, girl's education is badly affected. There is a positive correlation between household income and school attendance ${ }^{[14]}$. Many parents especially in large families with financial restrictions enroll boys in school instead of or before girls.

Gender inequality in schooling has received considerable attention worldwide. Many developing countries, including Ghana have been struggling with the issues of achieving gender equality for several decades ${ }^{[9]}$. The 1990 World Conference on "Education for All" in Jomtien, Thailand, placed emphasis on female education not only as a fundamental right, but also as an important means for economic and social development ${ }^{[13]}$.

In order to safeguard the interest of these children and to bridge the gender gap, many Non-Governmental Organizations work in education in order to complement the government's effort in various countries. For instance, the British Department for International Development (DFID) is actively engaged in the support and promotion of the girlchild education in Ghana. They support in the distribution of school uniforms, bicycles, school bags, sandals, exercise books, pens, and pencils and other educational materials to the girl-child in the various schools in Ghana ${ }^{[3]}$.

UNICEF is involved in a similar exercise of promoting girl-child education in order to reduce the gender gap in education ${ }^{[13]}$. The Campaign for Female Education (CAMFED) is a non-governmental organization whose main activity is to work to improve the disparity that exists between the boy and the girl-child in formal education ${ }^{[8]}$.

The Girls' Education Unit was established in the Ghana Education Service in 1997 under the auspices of the Free Compulsory and Universal Basic Education Program (FCUBE) with the intermediate objective of playing a strong supporting role in the field at all levels of bilateral and multilateral agencies working in partnership with governmental and other organizations towards the achievement of equitable participation of girls in education as a development goal ${ }^{[14]}$.

\subsection{Context}

Pre-tertiary education in Ghana comprises 11 years of basic education which is made up of 2 years Kindergarten, 6 years primary and 3 years Junior High School education and 3 years Senior High School education. Research shows that after Junior High School, many girls are unable to continue to Senior High School ${ }^{[7,11]}$. This is partly because many government interventions are focused at the basic education level therefore creating a gap at the Senior High School level coupled with the fact that many people still see female as belonging to the kitchen and therefore prefer to send their males children to school and leave females at home. There have however been efforts by stakeholders such as NGOs to promote female education in Ghana.

The inequity in female education is still greater than males and it impacts the rural communities more deeply, which is serious, because the high proportion of the population in Ghana is still rural ${ }^{[21]}$. Also, literacy achievement in Ghana has risen steadily over the years. Compared to the 2000 statistics, the level of literacy has increased from 54.1 percent to 71.5 percent in $2010{ }^{[10]}$. This change is more visible related to females; it has increased $19.6 \%$ and for males, the increase was $15.4 \%$. In contrast, there is still a gap regarding girl's education. $80.2 \%$ of males are more literate and just $68.5 \%$ of females are literate. At the same time, the percentage of children that never attend school is greater for females $(14.3 \%)$ than males (9.1\%). On the other hand, the employment rate is higher for males $(25.3 \%)$ than for females $(11.4 \%)$; nevertheless, the rate for informal self-employment is superior for females $(69.4 \%)$ than males $(60 \%)^{[2]}$. This clearly indicates shows that more needs to be done to enhance female education in Ghana and specifically in the Gomoa West District. 
In rural areas, where economic poverty and traditional practices are higher, illiteracy affects more women than men. About $29 \%$ of females are literate compared to $52 \%$ of males in rural areas in Ghana ${ }^{[19]}$. Ghana is a developing country where the majority of children face many difficulties to attend school; however, this problem is greater regarding economically impoverished girls. There has been important reform aimed to find a solution to the higher percentage of illiteracy regarding girls ${ }^{[20]}$.

\subsection{Problem statement}

The United Nations has asserted that education "is especially significant for girls and women because it is an entry point to other opportunities, also because the educational achievements of women can have ripple effects within the family and across generations" ${ }^{[14,7]}$.

Without educating women, national endeavours can be less effective and the efforts of women weaker ${ }^{[15]}$. The significant contribution of female education is expressed in terms of economic, cultural and political aspect of a country. An educated female is likely to become a more competent and knowledgeable mother, a more productive and better paid worker, an informed citizen, a self-confident individual and a skilled decision maker ${ }^{[15]}$.

There is a positive relationship between female education and improved household incomes and nourishment ${ }^{[4]}$. Education is seen as a single most important contributor to national economic growth, self-sufficiency and cultural reawakening of a people ${ }^{[1,3,6]}$.

However, the level of education of women in African countries such as Nigeria and Ghana is generally low ${ }^{[13]}$. Specifically, in Ghana 41 percent of females above 18 years had never been to school as against 21 percent of males. Similarly, 38 percent of females had only primary education and only six percent of female's level of educational was higher than secondary education ${ }^{[12]}$.

The rural areas and fishing communities in Ghana are the most disadvantaged areas in terms of access and participation in tertiary education ${ }^{[10]}$. Therefore, efforts must be concentrated on such disadvantaged communities in order to reduce the high illiteracy rate among the women folks.

In order to achieve the objective of high literacy rate among women, the MoESS, the World Bank and UNICEF have raised great concern regarding awareness and firm commitment in improving girls' education in Ghana. It was followed by the development of a National Plan which affirmed the need to empower women through education for national development ${ }^{[10,13]}$.

Also, with the establishment of the Girls' Education Unit in 1997, it was expected that the needs and concerns of the girl-child including female senior high school (SHS) graduates especially, in deprived regions, districts and communities will not only be adequately and effectively addressed but also the dropout rate for girls in high schools will be reduced drastically ${ }^{[10]}$.

Efforts to boost female education have been made by governments, international organizations and NGOs. However, there are still some loopholes in education with regard to access and participation. Some of the loopholes are that females still have low access to education, low participation and poor performance in many subjects, especially mathematics, science and technical subjects ${ }^{[10]}$.

Literature abounds various stakeholders' perspective about female education and affirmative action in Senior High Schools in Ghana, however, there appeared to be little literature on the girl child perceive female education in their districts. The study therefore seeks to explore the perception of the girl child about female education and affirmative action in the Gomoa West District, Central Region of Ghana.

\subsection{The purpose of the study}

The study explored the perspectives of female Senior High School students in Gomoa West District of the Central Region of Ghana on the factors that impede female education in Senior High Schools as well as examine measures put in place by stakeholders to promote female education in the District.

\subsection{Research questions}

The study was guided by the following research questions:

(1) What factors impede female education in the Gomoa West District?

(2) How are the measures put in place by stakeholders to promote female education in the district?

(3) How do female students perceive the success of female education in the district?

\section{Methodology}

The study adopted descriptive survey. In the study, the population comprised all the female students of the three 
Senior High Schools in Gomoa West district. The researchers used simple random sampling techniques to select 200 female students from the three Senior High Schools in the district to respond to items on a questionnaire.

\subsection{Research area}

The research site was Gomoa West District. According to Ghana Statistical Service, legislative Instrument (L1) 1896 following the division of the former Gomoa District into two, Gomoa West and Gomoa East Districts established Gomoa West District in July 2008. Apam is its District Capital ${ }^{[21]}$.

The 2010 Population and Housing Census recorded 135,189 as the population of the district, which is about 6 . I\% of the regional population. There are 60,417 males, which constitute 44.7 percent of the total population, and 74,772 females, which also constitute (55.3\%). The population in the urban areas is 57,568 (42.6\%) and in the rural areas we have 77, 62 I $(57.4 \%)$.

The main economic activities of the people are farming, that is crops and livestock, fishing, mining and quarrying, tourism, commerce and services, manufacturing and agro-processing. The main occupations of the people are farming and fishing since the area lies in a forest and coastal belt respectively, where the land is fertile for the cultivation of food crops such as cocoyam, plantain, yam, banana and vegetables. The people are mainly fishermen, artisans, auto and radio mechanics, sewing, and masonry, woodcarving, Beads- making, black smiting, sign writing and painting.

The technological and socio-economic development of the District depends largely on access to quality education of its people. The district has 343 educational institutions, comprising 126 Nurseries/Kindergarten, 132 Primary, 77 Junior High Schools and 8 Senior High Schools Ghana ${ }^{[21]}$.

Sample collection: Two hundred female students of the three Senior High Schools in the Gomoa West district. The sample size of the female students for each Senior High School was determined using the proportional allocation procedure.

The five Senior High Schools under study were: Apam Senior Secondary School, Gomoa Senior High/Technical School and Mozano Senior High School.

The formula used for the proportional allocation procedure was; $\mathrm{S}=\mathrm{n} / \mathrm{N} \times 100$

Where: $\mathrm{S}=$ School, $\mathrm{n}=$ Number of female students in each Senior High School, $\mathrm{N}=$ Overall total number of female students in all the three Senior High Schools and 200 is the sample size of female students of all the three Senior High Schools.

\subsection{Instrumentation}

Data was collected by means of a questionnaire developed by the researchers.

The questionnaire was close-ended but the last part, thus part " $\mathrm{D}$ " of the questionnaire had open-ended items. The questionnaire was divided into four parts, the first part "A" explored the bio data of the respondents, the second part "B" of the questionnaire consisted of a four point.

Likert scale which involved " 4 = Strongly Agree, 3 = Agree, 2 = Disagree and 1 = Strongly Disagree", which looked at factors negatively influence female education in the district, the third part " $\mathrm{C}$ " looked at measures put in place by stakeholders to promote female education in the district and the fourth part " $D$ " explored how female students perceive the success of female education in the district.

The researchers conducted an open-ended interview with 15 female students out of the 200 female students. This interview guide which contained 7 items was designed by the researchers to explore a deeper understanding and more information about female education in the district, since these female students were student leaders who interact with management of the school every day.

\subsection{Validity and reliability}

The research instruments were given to experts and colleagues to establish the face validity of the instruments. They were requested to carefully and systematically scrutinize and assess the instruments for its relevance and face validity. Issues such as length of questions, framing of questions, and ambiguity were considered. The feedback from colleagues was factored into the final preparation of the instruments. Also, suggestions of my colleagues were sought to content validate the instruments.

The Cronbach alpha value for questionnaire was .73. Experts argue that Cronbach alpha coefficient should be at least .70 to be indicative of high reliability. Based on these assertions, the instruments are judged to be of high reliability and therefore suitable for data collection for this study. 


\subsection{Ethical issues}

\subsubsection{Confidentiality}

The participants were assured that all the information obtained would be treated as confidential. That is, data were only used for stated purposes and no other person had access to them. The names of participants and schools were coded and not released in the research. Also, the names of participants were not needed on the questionnaire and respondents were informed before they filled the questionnaire. The learning atmosphere in the schools were not disturbed during the data collection process and the data collected through questionnaires, the data collection process was kept confidential and made available only to persons who had direct interest in this study. Computer data were protected by a password. At the end of the process, all documents were shredded and tapes were deleted.

\subsubsection{Anonymity}

The researcher ensured that no one could identify the participants from the information provided. This was done by not indicating names, addresses and particular names of individual schools of participants. All these were not indicated in the formal report resented.

\subsection{Data analysis}

Quantitative data were collected through the questionnaire. Descriptive statistics in the form of frequency counts and percentages were used to analyze the quantitative data with the help of Statistical Product for Service Solution (SPSS) software version 20 .

The qualitative data obtained from the study were analyzed thematically. Based on the responses to the items, codes were assigned to each item, and themes were identified in the process. The responses were then organized into the themes and analyzed.

\section{Results and discussion}

Research Question 1. What factors impede female education in the Gomoa West District?

\begin{tabular}{|c|c|c|c|c|c|c|c|c|}
\hline \multirow{2}{*}{ Items } & SA & A & $\mathbf{S A}+\mathbf{A}$ & D & SD & $\mathbf{D}+\mathbf{S D}$ & \multicolumn{2}{|c|}{$\mathbf{T}$} \\
\hline & F $\quad(\%)$ & F $(\%)$ & F $\quad(\%)$ & F $(\%)$ & F $(\%)$ & F $\quad(\%)$ & $\mathbf{F}$ & (\%) \\
\hline $\begin{array}{l}\text { Cultural practices and entrenched } \\
\text { beliefs }\end{array}$ & $39(19.5)$ & $95(47.5)$ & $134(67)$ & $56(28)$ & $10(5)$ & $66(33)$ & 200 & 100 \\
\hline Poverty & $101(50.5)$ & $69(34.5)$ & $170(85)$ & $23(11.5)$ & $7(3.5)$ & $30(15)$ & 200 & 100 \\
\hline Low level of education of parents & $92(46)$ & $63(31.5)$ & $155(77.5)$ & $34(17)$ & $11(5.5)$ & $45(22.5)$ & 200 & 100 \\
\hline Unconducive school environment & $48(24)$ & $97(48.5)$ & $145(72.5)$ & $47(23.5)$ & $8(4)$ & $55(27.5)$ & 200 & 100 \\
\hline Early marriages & $67(33.5)$ & $71(35.5)$ & $138(69)$ & $55(27.5)$ & $7(3.5)$ & $62(31)$ & 200 & 100 \\
\hline Teacher Absenteeism & $32(16)$ & $79(39.5)$ & $111(55.5)$ & $63(31.5)$ & $26(13)$ & $89(44.5)$ & 200 & 100 \\
\hline $\begin{array}{l}\text { Parental negative attitude towards } \\
\text { education }\end{array}$ & $66(33)$ & $68(34)$ & $134(67)$ & $56(28)$ & $10(5)$ & $66(33)$ & 200 & 100 \\
\hline $\begin{array}{l}\text { Inadequate parental attention to } \\
\text { daughter's education }\end{array}$ & $68(34)$ & $74(37)$ & $142(71)$ & $50(25)$ & $8(4)$ & $58(29)$ & 200 & 100 \\
\hline High discrimination of girl child & $70(35)$ & $72(36)$ & $142(71)$ & $38(19)$ & $20(10)$ & $58(29)$ & 200 & 100 \\
\hline $\begin{array}{l}\text { Inadequate of proper security } \\
\text { arrangements }\end{array}$ & $40(20)$ & $79(39.5)$ & $119(59.5)$ & $57(28.5)$ & $24(12)$ & $81(40.5)$ & 200 & 100 \\
\hline
\end{tabular}

Results from the Table 1, it is observed that, greater number of female students thus, $67 \%$ agreed to cultural practices and entrenched beliefs impede female education while a smaller number thus, 33\% disagreed, $85 \%$ agreed and $15 \%$ disagreed that poverty impede female education, $77.5 \%$ agreed whiles $22.5 \%$ disagreed low level of education of parents impede female education, $72.5 \%$ agreed and $27.5 \%$ disagreed that unconducive school environment impede female 
education, $69 \%$ agreed but $31 \%$ disagreed that early marriages impede female education, $55.5 \%$ agreed whiles $44.5 \%$ disagreed teacher absenteeism impede female education, $67 \%$ agreed but $33 \%$ disagreed parental negative attitude towards education impede female education, $71 \%$ agreed while $29 \%$ disagreed that inadequate parental attention to daughter's education impede female education, $71 \%$ agreed however, $29 \%$ disagreed that high discrimination of girl child impede female education, $59.5 \%$ agreed but $40.5 \%$ disagreed that inadequate of proper security arrangements is one of the factors that impede female education in the district. negatively influence female education in the district.

Poverty, long-held negative attitudes about women's intellectual capabilities, teenage pregnancy, early marriage and the traditional division of household labour are among the many factors that continue to keep vast numbers of girls out of the classroom ${ }^{[2]}$. They further argue that the thinking of the rural man that the female's main office is the kitchen has contributed greatly to the low education of females in the country.

Unpunctuality of teachers; unfeasibility of school buildings; poor financial status of the parents; lack of basic facilities; marriage at early age; lack of parental attention; negative attitudes of parents about girls' education; illiteracy of the parents; lack of competent teachers; lack of basic facilities for teachers; lack of proper security arrangement; and long distance to school are factors that affect girls' education ${ }^{[17]}$.

Research Question 2: How are the measures put in place by stakeholders to promote girls' education in the District?

Table 2. Measures put in place by stakeholders to promote female education in the district

\begin{tabular}{|c|c|c|c|c|c|c|c|c|}
\hline \multirow{2}{*}{ Items } & SA & & $\mathbf{S A}+\mathbf{A}$ & D & \multirow{2}{*}{$\begin{array}{c}\text { SD } \\
\text { F }(\%)\end{array}$} & \multirow{2}{*}{$\begin{array}{l}\text { D }+ \text { SD } \\
\text { F }(\%)\end{array}$} & \multicolumn{2}{|c|}{$\mathbf{T}$} \\
\hline & F $\quad(\%)$ & F $\quad(\%)$ & F (\%) & F $\quad(\%)$ & & & $\mathbf{F}$ & $(\%)$ \\
\hline $\begin{array}{c}\text { Provision of basic educational } \\
\text { materials }\end{array}$ & 141(71.9) & $39(19.9)$ & $180(91.8)$ & $16(8.2)$ & $0(0)$ & $16(8.2)$ & 200 & 100 \\
\hline $\begin{array}{l}\text { Assisted in providing } \\
\text { educational training to girls }\end{array}$ & $55(27.5)$ & $18(9.0)$ & $73(36.5)$ & $127(63.5)$ & $0 \quad(0)$ & $127(63.5)$ & 200 & 100 \\
\hline $\begin{array}{l}\text { Assisted in providing girls with } \\
\text { basic needs }\end{array}$ & $104(52.0)$ & $51(25.5)$ & $155(77.5)$ & $45(22.5)$ & $0 \quad(0)$ & $45(22.5)$ & 200 & 100 \\
\hline $\begin{array}{l}\text { Influenced the perception } \\
\text { regarding girl education }\end{array}$ & $9-6(48.0)$ & $49(24.5)$ & $145(72.5)$ & $55(27.5)$ & $0(0)$ & $55(27.5)$ & 200 & 100 \\
\hline $\begin{array}{l}\text { Trained teachers to become } \\
\text { Teacher Mentors to mentor girls } \\
\text { in schools. }\end{array}$ & $52(26.0)$ & $24(12.0)$ & $76(38)$ & $121(60.5)$ & $3(1.5)$ & $124(62)$ & 200 & 100 \\
\hline $\begin{array}{l}\text { Involving more girls in school } \\
\text { activities and programs }\end{array}$ & $82(41.0)$ & $51(25.5)$ & $133(66.5)$ & $66(33.0)$ & $1(0.5)$ & $67(33.5)$ & 200 & 100 \\
\hline $\begin{array}{l}\text { Sensitizing community against } \\
\text { early child marriages }\end{array}$ & $71(35.5)$ & $58(29.0)$ & $129(64.5)$ & $71(35.5)$ & $0 \quad(0)$ & $71(35.5)$ & 200 & 100 \\
\hline $\begin{array}{l}\text { Educating young girls on } \\
\text { adolescent reproductive health }\end{array}$ & $95(47.5)$ & $64(32.0)$ & $159(79.5)$ & $41(20.5)$ & $0(0)$ & $41(20.5)$ & 200 & 100 \\
\hline $\begin{array}{l}\text { Contribute to raising awareness } \\
\text { in the district on Girl Child } \\
\text { Education }\end{array}$ & $100(50.8)$ & $46(23.0)$ & $146(73.8)$ & $51(25.5)$ & $0(0)$ & $51(25.5)$ & 200 & 100 \\
\hline $\begin{array}{l}\text { Providing basic facilities for } \\
\text { schools }\end{array}$ & $51(25.5)$ & $67(33.5)$ & $118(59)$ & $82(41.0)$ & $0(0)$ & $82(41.0)$ & 200 & 100 \\
\hline $\begin{array}{l}\text { Awareness creation on } \\
\text { discrimination against girl child } \\
\text { in schools and homes }\end{array}$ & $65(32.5)$ & $60(30.0)$ & $125(62.5)$ & $75(37.5)$ & $0(0)$ & $75(37.5)$ & 200 & 100 \\
\hline $\begin{array}{l}\text { Motivating teachers to support } \\
\text { girls in school against violence }\end{array}$ & $48(24.0)$ & $72(36.0)$ & $120(60)$ & $80(40.0)$ & $0(0)$ & $80(40.0)$ & 200 & 100 \\
\hline $\begin{array}{l}\text { Building capacity of teachers on } \\
\text { how to handle and support girls }\end{array}$ & $51(25.5)$ & $106(53.0)$ & $157(78.5)$ & $43(21.5)$ & $0(0)$ & $43(21.5)$ & 200 & 100 \\
\hline
\end{tabular}

Results from the Table 2, it is observed that, greater number of female students thus, $91.8 \%$ agreed while $8.2 \%$ that provision of basic educational materials is a measure put in place by stakeholders to promote female education in the district, $36.5 \%$ agreed but $63.5 \%$ disagreed stakeholders in the district assisted in providing educational training to girls, $77.5 \%$ agreed while $22.5 \%$ disagreed that stakeholders assisted in providing girls with basic needs, $72.5 \%$ agreed that stakeholders influenced the perception regarding girl education but $27.5 \%$ disagreed, $38 \%$ agreed while $62 \%$ disagreed that 
teachers are trained to become Teacher Mentors to mentor girls in schools., $66.5 \%$ agreed that stakeholders involved more girls in school activities and programs while 33.5\% disagreed, $64.5 \%$ agreed whereas $35.5 \%$ disagreed that stakeholders sensitized community against early child marriages, $79.5 \%$ agreed young girls educated on adolescent reproductive health, however, $20.5 \%$ disagreed. $73.8 \%$ agreed that stakeholders contributed to raising awareness in the district on Girl Child Education but $25.5 \%$ disagreed, $59 \%$ agreed while $41 \%$ disagreed that stakeholders provided basic facilities for schools, $62.5 \%$ agreed that stakeholders created awareness on discrimination against girl child in schools and homes but $37.5 \%$ disagreed, $60 \%$ agreed teachers are motivated to support girls in school against violence, however, $40 \%$ disagreed. $78.5 \%$ agreed while $21.5 \%$ disagreed that building capacity of teachers on how to handle and support girls is one of the measures put in place by stakeholders to promote female education in the district.

Non-Government Organizations (NGOs) working in education often grant scholarship packages which include the sensitization of the public about the need for the girl-child education, assistance to the families of the girl-child, distribution of school uniforms, payment of tuition fees, bags, and bicycles especially to the rural girl-child ${ }^{[7]}$.

NGOs through their scholarships have championed the cause of the girl child through the provision of funding, technical assistance, information sharing and capacity building. Such activities outside of central government has formed the pillar of interventions in girls' education to date ${ }^{[8]}$.

The Campaign for Female Education (CAMFED) is a non-governmental organization whose main activity is to work to improve the disparity that exists between the boy and the girl-child in formal education ${ }^{[8]}$.

The British Department for International Development (DFID) is actively engaged in the support and promotion of the girl-child education in Ghana. They support in the distribution of school uniforms, bicycles, school bags, sandals, exercise books, pens, and pencils to the girl-child in the various schools in Ghana ${ }^{[16]}$.

The Girls' Education Unit established in the Ghana Education Service in 1997 plays a strong supporting role in the field at all levels of bilateral and multilateral agencies working in partnership with governmental and other organizations towards the achievement of equitable participation of girls in education as a development goal ${ }^{[14]}$.

Research Question 3: How do female students perceive the success of female education in the District?

Table 3. Measures that have been put in place by stakeholders to promote female education

\begin{tabular}{|c|c|c|}
\hline $\begin{array}{l}\text { Are you satisfied with the measures that have been put in place by stakeholders to promote } \\
\text { female education? }\end{array}$ & $\mathbf{F}$ & $\%$ \\
\hline Very Satisfied & 108 & 54.0 \\
\hline Satisfied & 69 & 34.5 \\
\hline Not satisfied & 3 & 1.5 \\
\hline Very not satisfied & 20 & 10.0 \\
\hline Total & 200 & 100 \\
\hline
\end{tabular}

Results from the Table 3, showed $88.5 \%$ of female students are satisfied with measures put in place by stakeholders in the district to promote female education in the district whiles $11.5 \%$ are not satisfied with the measures stakeholders have put in place.

Table 4. Effectiveness of measures in promoting female education

\begin{tabular}{ccc}
\hline How effective have these measures been in promoting female education? & F & \% \\
\hline Very effective & 39.0 & 78 \\
Effective & Ineffective & 112 \\
Total & 56.0 & 10 \\
\hline
\end{tabular}

With regards to how effective how the measures are in promoting female education in the district, greater number of female students thus $95 \%$, believe that these measures are effective while a lesser number of $5 \%$ believe that these measures are not effective.

Table 5. Level in involvement of female in school activities and student leadership

\begin{tabular}{|c|c|c|}
\hline What is the level of involvement of female in school activities and student leadership? & $\mathbf{F}$ & $\%$ \\
\hline Very involved & 113 & 56.5 \\
\hline Involved & 85 & 42.5 \\
\hline Not involved & 2 & 1.0 \\
\hline Total & 200 & 100 \\
\hline
\end{tabular}


Results from the Table 5, showed $88.5 \%$ of female students are satisfied with measures put in place by stakeholders in the district to promote female education in the district whiles $11.5 \%$ are not satisfied with the measures stakeholders have put in place.

Table 6. Educational policies that support female participation in schools

\begin{tabular}{|c|c|c|}
\hline Do you think current educational policies support female participation in schools? & $\mathbf{F}$ & $\%$ \\
\hline Yes & 184 & 92.0 \\
\hline No & 16 & 8.0 \\
\hline Total & 200 & 100 \\
\hline
\end{tabular}

Results from the Table 2, it is observed that, greater number of female students thus, 92\% agreed that current educational policies support female participation in schools whiles a lesser number, $8 \%$ disagreed with the factor that current educational policies support female participations in schools.

Table 7. Impact of current educational policies on female education at SHS

\begin{tabular}{|c|c|c|}
\hline $\begin{array}{l}\text { Do you think the current educational policies have had any impact on female education at the } \\
\text { SHS? }\end{array}$ & $\mathbf{F}$ & $\%$ \\
\hline Great impact & 134 & 67.0 \\
\hline Impact & 46 & 23.0 \\
\hline Less impact & 17 & 8.5 \\
\hline Very less impact & 3 & 1.5 \\
\hline Total & 200 & 100 \\
\hline
\end{tabular}

With regards to how impactful current educational policies are on the female education at the Senior High Schools, majority of females representing $90 \%$ agreed that these policies are impactful, however, a minority of $10 \%$ disagreed.

\section{Conclusion}

There are many factors which impede female education at Senior High Schools in Gomoa West district. These factors include cultural practices and entrenched beliefs, poverty, low level of education of parents, unconducive school environment, early marriages, teacher absenteeism, parental negative attitude towards education, inadequate parental attention to daughter's education, high discrimination of girl child, inadequate of proper security arrangements.

Also, measures such as provision of basic educational materials, provision of educational training to girls, provision of girls with basic needs, influencing the perception of parents regarding girl education, training of teachers to become Teacher Mentors to mentor girls in schools., involving more girls in school activities and programs, sensitizing community against early child marriages, educating young girls on adolescent reproductive health, contribute to raising awareness in the district on Girl Child Education, providing basic facilities for schools, awareness creation on discrimination against girl child in schools and homes, motivating teachers to support girls in school against violence, building capacity of teachers on how to handle and support girls, were put in place by stakeholders to promote female education in the district.

It is also observed that, female students were satisfied with measures put in place by stakeholders in the district to promote female education in the district, they also believed that measures and educational policies put in place to promote female education in the district were effective and impactful. Female students were also involved in school leadership and they fully participate in school activities in school.

\section{Recommendations}

The Government of Ghana, Ministry of Education, Ghana Education Service, and the Gomoa West District Education Office to encourage Non-Governmental Organizations and other stakeholders to continue to do more in providing girls in Senior High School with basic bursary items to enable them enroll in school, stay in and complete school successfully. These Non-Governmental Organizations and other stakeholders should be given the needed support to function properly in helping female education in the district.

In addition, the same in-service training should be used by the Government of Ghana, Ministry of Education, Ghana Education Service, the Gomoa West District Education Office, Non-Governmental Organizations and other stakeholders in the Gomoa West District to sensitize, orient and reorient teachers and other staff members of the various Senior High Schools on gender issues to enable them acquire the necessary skills in dealing with girls in their respective schools. 


\section{References}

[1] Abosi, C. O., Brokman-Amissah, J. Introduction to education in Ghana. Accra: Sedco Publishing Limited; 2002.

[2] Adetunde, I. A., \& Akensina, A. P. Factors Affecting the Standard of Female Education: A Case Study of Senior Secondary Schools in the Kassena-Nankana District. Journal of Social Sciences. 2008; 4(4): 338-342.

[3] Ahmed, M., Ahmed, \& M. Bangladesh education sector overview. Japan Bank for International Cooperation (JBIC), 2002; 2(4): 23-34.

[4] Anamuah-Mensah, J. The race against underdevelopment: A mirage or reality. Accra: Ghana Universities Press. 2000.

[5] Ball, S. J. Politics and Policy Making in Education: explorations in policy sociology. London: Routledge; 1990.

[6] Bank, W. World development report: Knowledge for development. New York: Oxford University Press; 2001.

[7] CAMFED. CAMFED Resources: Annual Reports,Strategic Plan, and Impact Reports. 2008. Retrieved from https:// camfed.org/why-girls-education/resources/

[8] CAMFED. CAMFED Impact. 2019. Retrieved from https://camfed.org/latest-news/one-million-girls-update/

[9] Engin-Demir, C. Factors affecting the academic achievement of Turkish Urban Poor. International Journal of Educational Development. 2009; 29(1): 17-29.

[10] Ghana Education Service. Annual report. Accra: GES; 2012.

[11] King, M. E., \& Hill , M. A. Women's Education in Developing Countries: Barriers, Benefits, and Policies. The Journal of Developing Areas. 1993; 29(2): 286-288.

[12] Ministry of Education, Science \& Sports. Preliminary education sector performance report. Accra: Government of Ghana; 2012.

[13] National Development Planning Commission [NDPC]. Annual progress report:Ghana Poverty Reduction Strategy II. Accra: Government of Ghana; 2012.

[14] National Development Planning Commission [NDPC]. Implementation of the mid-term development plan. Accra: Government of Ghana; 2013.

[15] Obanya, P. "Promoting Basic Education for Women and Girls". Paris: UNESCO; 2005.

[16] Organisation for Economic Co-operation and Development Development Centre [OECD]. Gender inequality and the MDGs: What are the missing dimensions? Issues Brief. Paris: OECD; 2013.

[17] Suleman, Q., Aslam, D. H., Habib, B. M. et al. Exploring Factors Affecting Girls' Education at Secondary Level: A Case of Karak District, Pakistan. Journal of Education and Practice; 2015; 6(19): 95-109.

[18] West African Examination Council [WAEC] . General resume of the chief examiners' reports on the standard of the papers. Accra: WAEC Ghana; 2012.

[19] Food and Agricultural Organization (FAO). Gender Inequalities in Rural Employment in Ghana. An Overview. 2012. Available from: http://www.fao.org/docrep/016/ap090e/ ap090e00.pdf. [Accessed 17 ${ }^{\text {th }}$ March, 2020]

[20] Agbemabiese-Grooms, K. "I want to go to school, but I can't": Examining the factors that impact the Anlo ewe girl child's formal education in Abor, Ghana. 2011. Available from: http://ezproxy.viu.ca/login?url=http://search.proquest. com/docview/902759326? accounted=12246. [Accessed $17^{\text {th }}$ March, 2020]

[21] Ghana Statistical Service. Population \& housing census. 2014. Available from: http://www.statsghana.gov.gh/ docfiles/2010phc/Census2010_Summary_report_of_fial_results.pdf. [Accessed 16th March, 2020] 